\title{
Risiko og nytte ved hjernesvulstoperasjoner
}

\author{
Tidlig kirurgi ved diffuse gliomer har positiv effekt på overlevelse. \\ Gevinsten må balanseres mot pasientenes livskvalitet, siden nevro- \\ logiske utfall relatert til operasjonen gir et tydelig fall i livskvalitet.
}

Diffust infiltrerende gliomer er den vanligste formen for primære hjernesvulster hos voksne. Det har vært store variasjoner i kirurgisk praksis for pasienter med diffuse gliomer. Nøye vurdering av kirurgiske resultater og strategier er viktig for disse pasientene som per i dag ikke har tilbud om kurativ behandling. I våre studier har vi belyst ulike strategier og sett på flere effektmål etter kirurgi for hjernesvulster, med hovedvekt på diffuse gliomer.

Vi fant at forskjeller i pasientseleksjon samt den lave forekomsten av perioperativ død ved hjernesvulstoperasjoner gjør perioperativ død til et problematisk endepunkt i sammenliknende studier. Videre observerte vi at nye nevrologiske utfall etter kirurgi gir et tydelig fall i livskvalitet, i alle fall på kort sikt. For de mest aggressive svuls- tene er også et tidlig fall i livskvalitet assosiert med kortere overlevelse. Livskvalitet som endepunkt gir et mer nyansert bilde enn tradisjonell funksjonsskår og bidrar også til en pasientsentrert tilnærming, noe som kan være nyttig når man vurderer effekten $\mathrm{av}$ kirurgi.

Studien i avhandlingen om kirurgisk håndtering av lavgradige gliomer ble publisert i JAMA i 2012 med resultater som direkte kan påvirke klinisk praksis. Vi fant at initial behandlingsstrategi ved lavgradige gliomer bør være tidlig kirurgisk reseksjon, ettersom dette gir en klar overlevelsesgevinst.

\section{Asgeir Store Jakola}

asgeir.jakola@stolav.no

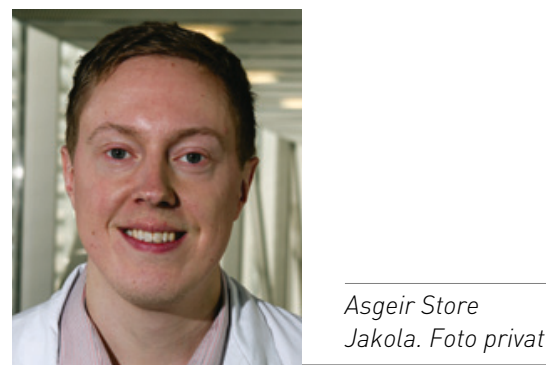

Disputas

Asgeir Store Jakola disputerte for ph.d.-graden ved Norges teknisk-naturvitenskapelige universitet 31.5. 2013. Tittelen på avhandlingen er Risks and benefits of brain tumor surgery a balancing act

\section{Bedre forståelse av muterende enzym}

\author{
Distribusjon og transport av enzymet aktiveringsindusert cytidin- \\ deaminase (AID) i celler regulerer antistoffmodning i B-celler.
}

Aktiveringsindusert cytidin-deaminase (AID) er essensielt i aktiverte B-celler for utvikling av spesifikke antistoffer. Det er det eneste proteinet i kroppen som aktivt muterer genomet vårt under fysiologiske forhold. Som DNA-muterende enzym er AID potensielt farlig. Uregulert aktivitet er assosiert med utvikling av B-cellelymfom og en rekke andre kreftformer samt autoimmune sykdommer. Kartlegging av mekanismer som regulerer enzymet er dermed betydningsfullt.

Intracellulær proteintransport er en viktig reguleringsmekanisme. Hvordan AID transporteres inn til cellekjernen var omdiskutert i litteraturen. Våre studier har vist at kjerneimport av dette enzymet er en aktiv og energikrevende prosess. Vi har i detalj kartlagt dets kjernelokaliseringssignal og funnet ut at dette signalet også dirigerer AID til nukleoli. Vi oppdaget en viktig sammenheng - at enzy- mets biologiske funksjon reguleres av kjerneimporthastighet sammen med enzymaktivitet.

Innhold $\mathrm{i}$ en cellekjerne er ofte funksjonelt fordelt i ulike kjernestrukturer. Gjennom systematisk observasjon av levende og fikserte celler oppdaget vi at AID befinner seg i strukturer relatert til mRNA-spleising, slik som Cajal-legemer og «nuclear speckles». Dette funnet åpner spennende muligheter for å forstå hvordan AID genererer måltrettede mutasjoner.

Våre resultater avklarer noen tidligere kontroverser i fagfeltet, gir innsikt og danner nye hypoteser i mekanismer bak den adaptive immunresponsen. Kunnskapen bidrar også til bedre forståelse for hvordan uregulert AID-aktivitet fører til sykdom.

\section{Yi Hu}

yihooyi@gmail.com

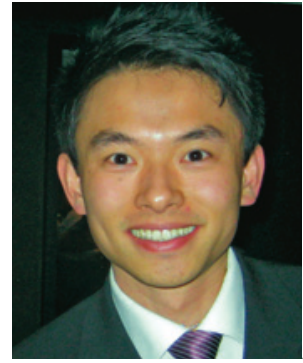

Yi Hu.

Foto Yuping Bai

\section{Disputas}

Yi Hu disputerte for ph.d.-graden ved Norges teknisk-vitenskapelige universitet 30.4. 2013. Tittelen på avhandlingen er Intracellular and subnuclear trafficking of activation induced cytidine deaminase (AID). 